\title{
HUBUNGAN ANTARA KONSUMSI JAMU SAAT HAMIL DENGAN KEJADIAN ASFIKSIA BAYI BARU LAHIR DI RUANG MELATI RSUD JOMBANG
}

\author{
Widya Anggraeni ${ }^{1 *}$, Kurnia Indriyanti Purnama Sari ${ }^{1}$, Riska Aprilia Wardani ${ }^{1}$ \\ ${ }^{1}$ STIKES Dian Husada Mojokerto \\ *Correspondence: \\ Widya Anggraeni \\ Email: widyainggit11@gmail.com
}

\begin{abstract}
Background: Jamu adalah obat jadi atau ramuan bahan alam yang berasal dari tumbuhan, hewan, mineral, sediaan galenik atau campuran bahan tersebut yang secara tradisional. Sementara ini banyak orang beranggapan bahwa penggunaan tanaman obat atau obat tradisional relatif lebih aman dibandingkan obat sintesis. Berdasarkan studi pendahuluan di Ruang Melati RSUD Jombangsecara wawancara pada 10 ibu bersalin didapatkan $8(80 \%)$ ibu pernah mengkonsumsi jamu selama hamil dan $4(40 \%)$ bayi yang dilahirkan mengalami asfiksia berat, $3(30 \%)$ bayi baru lahir dengan asfiksia sedang dan 1 (10\%) bayi tidak mengalami asfiksia. Sedangkan 2 (20\%) ibu yang tidak pernah mengkonsumsi jamu selama hamil, bayi yang dilahirkan tidak mengalami asfiksia.

Purpose: Tujuan penelitian mengetahui hubungan antara konsumsi jamu saat hamil dengan pada ibu post partum di Ruang Melati RSUD Jombang.

Method: Desain penelitian anlitik cross sectional. Populasinya adalah semua ibu nifas di Ruang Melati RSUD Jombang sebanyak 38 orang dengan jumlah sampel 32 responden, teknik sampling yang di gunakan Accidental Sampling. Alat ukur kuesioner. Variabel independent konsumsi jamu saat hamil, variabel dependent kejadian asfiksia bayi baru lahir. Uji statistik menggunakan Chi Square.

Results: Berdasarkan hasil penelitian sebagian besar responden pernah mengkonsumsi jamu saat hamil sejumlah 20 responden $(62,5 \%)$. Hampir setengah bayi baru lahir mengalami asfiksia sejumlah 18 orang (56,3\%). Hasil uji chi square, didapatkan $\rho=0,000<0,05$, maka H0 ditolak atau H1 diterima artinya ada hubungan antara konsumsi jamu saat hamil dengan kejadian asfiksia pada bayi baru lahir di Ruang Melati RSUD Jombang.

Conclusion: Berdasarkan hasil penelitian diharapkan tenaga kesehatan dapat memberikan informasi tentang efek samping minum jamu sehingga ibu tahu tentang efek samping minum jamu saat hamil.

Key words: konsumsi jamu, asfiksia, kehamilan
\end{abstract}

\section{PENDAHULUAN}

Penggunaan bahan alam, baik sebagai obat maupun tujuan lain cenderung meningkat, terlebih dengan adanya isu Back to Nature serta krisis berkepanjangan yang mengakibatkan turunnya daya beli masyarakat. Obat tradisional dan tanaman obat banyak digunakan masyarakat menengah kebawah terutama dalam upaya preventif, promotif dan rehabilitatif (Jonathan, 2009). Jamu adalah obat jadi atau ramuan bahan alam yang berasal dari tumbuhan, hewan, mineral, sediaan galenik atau campuran bahan tersebut yang secara tradisional telah digunakan untuk pengobatan berdasarkan pengalaman (Sudibyo, 2009). Sementara ini banyak orang beranggapan bahwa penggunaan tanaman obat atau obat tradisional relatif lebih aman dibandingkan obat sintetis. Walaupun demikian bukan berarti tanaman obat atau obat tradisional tidak memiliki 
efek samping yang merugikan, bila penggunaannya kurang tepat, misalnya saat hamil banyak masyarakat beranggapan penting untuk mengkonsumsi jamu. Hasil penelitian Utami (2007) menyatakan fenomena yang ada di masyarakat adalah banyak ditemui ibu hamil yang mengkonsumsi jamu gendong seperti kunir asam dan cabe puyang dengan alasan setelah minum jamu tersebut rasa capek dan pegal hilang selain itu minum jamu sudah menjadi kebiasaan atau turun-temurun. Berdasarkan hasil penelitian di Surabaya pada tahun 2009 menunjukkan ada 62\% ibu hamil selalu mengkonsumsi jamu selama hamil misalnya cabe pucang, kunyit asam, anton-anton muda dan anton-anton tua. Alasan sebagian besar ibu adalah untuk kesehatan bayi di dalam kandungan, dan agar persalinan menjadi lancar (Rendra, 2009). Berdasarkan studi pendahuluan di Ruang Melati RSUD Jombang secara wawancara pada $10 \mathrm{ibu}$ bersalin didapatkan $8(80 \%)$ ibu pernah mengkonsumsi jamu selama hamil dan 4 (40\%) bayi yang dilahirkan mengalami asfiksia berat, 3 (30\%) bayi baru lahir dengan asfiksia sedang dan 1 (10\%) bayi tidak mengalami asfiksia. Sedangkan $2(20 \%)$ ibu yang tidak pernah mengkonsumsi jamu selama hamil, bayi yang dilahirkan tidak mengalami asfiksia.

Tujuan Umum Mengetahui hubungan antara konsumsi jamu saat hamil dengan kejadian asfiksia bayi baru lahir pada ibu post partum di Ruang Melati RSUD Jombang.

\section{METODE DAN BAHAN}

Dalam penelitian ini jenis penelitian yang digunakan adalah penelitian analitik korelasi. Sedangkan pendekatan penelitian yang digunakan adalah case control.
Populasi adalah semua ibu post partum di Ruang Melati RSUD Jombang sebanyak 32 orang.

Teknik pengambilan sampel menggunakan Sampling Non probability dengan jenis accidental sampling yaitu teknik pengambilan sampel berdasarkan kriteria dan waktu. Instrument yang digunakan adalah lembar observasi. Data yang diperoleh dianalisis dan disajikan dalam bentuk tabel frekuensi.

\section{HASIL PENELITIAN}

\section{Konsumsi Jamu Saat Hamil.}

Tabel 1. Konsumsi Jamu Saat Hamil Berdasarkan Waktu Konsumsi pada Ibu Hamil di Ruang Melati RSUD Jombang.

\begin{tabular}{|l|l|c|c|}
\hline No & $\begin{array}{l}\text { Mulai Minum } \\
\text { Jamu }\end{array}$ & Jumlah & $\begin{array}{c}\text { Persentase } \\
(\%)\end{array}$ \\
\hline 1. & Tidak Pernah & 12 & 37,5 \\
2. & Awal Kehamilan & 12 & 37,5 \\
3. & 4-7 bulan & 6 & 18,8 \\
4. & 8-9 bulan & 2 & 6,3 \\
\hline & Total & 32 & 100 \\
\hline
\end{tabular}

Berdasarkan tabel diatas terlihat bahwa lebih dari setengah (62,5\%) responden pernah konsumsi jamu saat hamil sejumlah 20 responden dan kurang dari setengah $37,5 \%$ tidak mengkonsumsi Jamu sebanyak 12 orang.

Tabel diatas terlihat bahwa sebagian besar responden tidak pernah memilih jenis jamu sejumlah 12 responden $(37,5 \%)$ dan mengkonsumsi jamu kunir asam sejumlah $12(37,5 \%)$. Berdasarkan tabel diatas terlihat bahwa kurang dari setengah $(37,5 \%)$ responden mengkonsumsi jamu pada awal kehamilan sejumlah 12 responden dan kurang dari setengah lagi $(37,5 \%)$ responden tidak pernah mengkonsumsi berbagai jenis jamu sejumlah 12 responden. 
2. Kejadian Asfiksia pada Bayi Baru Lahir.

Tabel 2. Angka Kejadian pada Bayi Baru Lahir di Ruang Melati RSUD Jombang.

\begin{tabular}{|l|l|c|c|}
\hline No & $\begin{array}{l}\text { Kejadian } \\
\text { Asfiksia BBL }\end{array}$ & Jumlah & Persentase (\%) \\
\hline 1. & Asfiksia & 18 & 56,3 \\
2. & Tidak Asfiksia & 14 & 43,8 \\
\hline & Total & 32 & 100 \\
\hline
\end{tabular}

Tabel diatas diketahui bahwa hampir setengah $(56,3 \%)$ bayi baru lahir mengalami asfiksia sejumlah 18 responden.

\section{Hubungan antara Konsumsi Jamu selama Hamil dengan Kejadian Asfiksia pada Bayi Baru lahir.}

Tabel 3. Analisa Hubungan antara Konsumsi Jamu selama Hamil dengan Kejadian Asfiksia pada Bayi Baru Lahir.

\begin{tabular}{|l|c|c|c|c|c|c|}
\hline \multirow{3}{*}{$\begin{array}{c}\text { Konsumsi } \\
\text { Jamu }\end{array}$} & \multicolumn{4}{|c|}{ Kejadian Asfiksia } & \multicolumn{2}{c|}{} \\
\cline { 2 - 7 } & \multicolumn{2}{|c|}{ Asfiksia } & \multicolumn{1}{c|}{$\begin{array}{c}\text { Tidak } \\
\text { Asfiksia }\end{array}$} & \multicolumn{2}{c|}{ Total } \\
\cline { 2 - 7 } & $\Sigma$ & $\%$ & $\Sigma$ & $\%$ & $\Sigma$ & $\%$ \\
\hline Pernah & 16 & 80,0 & 4 & 20,0 & 20 & 100,0 \\
\hline $\begin{array}{l}\text { Tidak } \\
\text { pernah }\end{array}$ & 2 & 16,7 & 10 & 83,3 & 12 & 100,0 \\
\hline Total & $\mathbf{1 8}$ & $\mathbf{5 6 , 3}$ & $\mathbf{1 4}$ & $\mathbf{4 3 , 8}$ & $\mathbf{3 2}$ & $\mathbf{1 0 0 , 0}$ \\
\hline
\end{tabular}

Berdasarkan hasil uji chi square, didapatkan bahwa $\rho=0,000<0,05$, maka H0 ditolak atau H1 diterima artinya ada hubungan yang sangat kuat antara konsumsi jamu saat hamil dengan kejadian asfiksia pada bayi baru lahir di Ruang Melati RSUD Jombang.

\section{PEMBAHASAN}

Perilaku yang didasari oleh pengetahuan akan lebih langgeng dibandingkan dengan perilaku yang tidak didasari oleh pengetahuan wanita yang memiliki pengetahuan lebih tinggi akan mempraktikkan perilaku konsumsi dengan benar (Notoatmodjo, 2008). Bila wanita hamil yang sedang sakit tidak boleh sembarangan minum obat karena bisa mempengaruhi janin di dalam kandungannya. Bisa menyebabkan janin cacat atau mengalami keguguran Penjualan jenis dan jumlah jamu gendong sangat bervariasi (Arfikoh, 2008). Obat tradisional merupakan obat jadi atau ramuan bahan alam yang berasal dari tumbuhan, hewan, mineral, sediaan galenik atau campuran bahan-bahan tersebut yang secara tradisional telah digunakan untuk pengobatan berdasarkan pengalaman. Pada kenyataannya bahan obat alam yang berasal dari tumbuhan porsinya lebih besar dibandingkan yang berasal dari hewan atau mineral, sehingga sebutan obat tradisional (OT) hampir selalu identik dengan tanaman obat (TO) karena sebagian besar OT berasal dari TO (Sudibyo, 2004). Asfiksia adalah keadaan dimana bayi baru lahir tidak dapat bernafas secara spontan dan teratur. Masalah ini erat hubungannya dengan gangguan kesehatan ibu hamil, kelainan tali pusat atau masalah yang mempengaruhi kesejahteraan bayi selama atau sesudah persalinan (JNPK-KR, 2007).

\section{SIMPULAN}

1. Sebagian besar $(62,5 \%)$ responden pernah konsumsi jamu saat hamil sejumlah 20 responden.

2. Hampir setengah $(56,3 \%)$ bayi baru lahir mengalami asfiksia sejumlah 18 orang.

3. Berdasarkan hasil uji chi square, didapatkan bahwa $\rho=0,000<0,05$, maka $\mathrm{H} 0$ ditolak atau $\mathrm{H} 1$ diterima artinya ada hubungan yang sangat kuat antara konsumsi jamu saat hamil dengan kejadian asfiksia pada bayi baru 
lahir di Ruang Melati RSUD Jombang.

\section{SARAN}

1. Diharapkan masyarakat dapat menggali informasi tentang efek samping konsumsi jamu selama kehamilan dari berbagai media seperti buku, tenaga kesehatan, radio, dan televisi.

2. Diharapkan tenaga kesehatan dapat memberikan informasi tentang efek samping minum jamu sehingga ibu tahu tentang efek samping minum jamu saat hamil.

3. Diharapkan institusi pendidikan dapat menambah wacana kepustakaan tentang dampak dari konsumsi jamu selama kehamilan.

4. Bagi peneliti selanjutnya diharapkan untuk melakukan penelitian tentang faktor lain yang mungkin mempengaruhi kejadian asfiksia pada persalinan.

\section{DAFTAR PUSTAKA}

1. Arfikoh. 2008. Jamu Tradisional. http://www.info-kia.com.id diakses tanggal 10 Agustus 2009.

2. Azis. 2006. Efek samping jamu. www.wartamedika.com diakses tanggal 13 Mei 2011.

3. Barbara. 2004. Minimnya Praktek Inisiasi Menyusu Dini. http://www.balipost.com. diakses tanggal 20 Maret 2009.

4. Bruner and Suddarth. 2005. Keperawatan Medikal Bedah Vol 1. Jakarta: EGC.

5. Budiarto. 2002. Biostatistika Untuk Kedokteran dan Kesehatan Masyarakat. Jakarta: EGC.

6. Canadian. 2005. Panduan Minum Jamu. Jakarta: Alfabeta.
7. Denisa. 2006. Permasalahan Selama Kehamilan. Jakarta: EGC.

8. Depkes. 2004. Tingginya Angka Kematian Ibu dan Bayi. http://www.depkes.com. diakses tanggal 25 Februari 2009.

9. Dinkes. 2003. Penatalaksanaan Komplikasi Bayi Baru Lahir. http://www.dinkes.com. diakses tanggal 11 April 2009.

10. Dinkes, Jombang.2008. Standar Pelayanan Minimal. http://www.dinkes-jmbg.com. diakses tanggal 14 Juli 2009.

11. Helen. 2004. Perawatan Maternitas. Jakarta: EGC.

12. Hidayat. 2003. Metodelogi Riset Keperawatan. Jakarta:PT.Rineka Cipta.

13. 2007. Metode Penelitian Kebidanan dan Tehnik Analisis Data. Jakarta: PT.Rineka Cipta.

14. James. 2009. Kemampuan Bayi Melakukan Inisiasi Menyusu Dini Selamatkan. http://www.info-kia.com. diakses tanggal 05 April 2009.

15. JNPK-KR. 2007. Asuhan Persalinan Normal. Jakarta : Ikatan Bidan Indonesia.

16. Jonathan. 2009. Maraknya Konsumsi Jamu Saat Hamil. http://www.infokia.com. diakses tanggal 13 Juni 2009.

17. Kartono. 2006. Perilaku Manusia. Jakarta: PT. Rineka Cipta.

18. Kardinan. 2007. Minum Jamu Selama Kehamilan. http://www.info-kia.com.id diakses tanggal 28 Februari 2009.

19. Nazir. 2005. Metode Penelitian. Bogor: Ghalia Indonesia.

20. Nelson. 2005. Ilmu Kesehatan Anak. Jakarta: EGC.

21. Notoatmodjo. 2005. Metodelogi Penelitian. Jakarta: PT. Rineka Cipta. 
22. Nursalam. 2008. Konsep Penerapan Metodologi Penelitian Ilmu Keperawatan. Jakarta: Salemba Medika.

23. Pratiwi. 2004. Psikologi Perkembangan. Jakarta: Ghalia Pustaka Utama.

24. Rendra. 2009. Jamu tradisional. http://www.info-kia.com.id diakses tanggal 14 Maret 2009.

25. Saifudin. 2006. Pelayanan Kesehatan Maternal dan Neonatal. Jakarta: Yayasan Bina Pustaka Sarwono Prawirohardjo.

26. Sarwono. 2005. Ilmu kebidanan. Yogyakarta: Yayasan Bina Pustaka Sarwono Prawirohardjo.

27. Setty. 2005. Efek Samping Minum Jamu Selama Hamil. http://www.infonakita.com. diakses tanggal 08 Maret 2009.

28. Soetjiningsih. 2004. Tumbuh Kembang Anak dan Remaja. Jakarta: FKUI.

29. Subroto.2006. Panduan Selama Hamil. http://www.motherandbaby.com. diakses tanggal 16 Agustus 2009.

30. Sudibyo. 2004. Obat tradisional. http://www.wikipedia.org/wiki/jamugendong diakses tanggal 17 Juli 2009.

31. Sugiyono. 2007. Statistik Untuk Kesehatan. Bandung: ALFABETA.

32. Utami.2008. Pengaruh Jamu Terhadap ASI. Jakarta: Pustaka Bunda.

33. Wang. 2007. Efek Samping minum Jamu Selama Kehamilan. http://www.info-online.com.id diakses tanggal 13 Maret 2009.

34. Welford.2007. ASI untuk kecerdasan bayi. Yogyakarta: Ayana.

35. Widodo.2008. Minum Jamu Selama Kehamilan.

http://www.wikipedia.com.id diakses tanggal 14 Januari 2009.
36. Winkjosastro.2004. Ilmu Kandungan. Yogyakarta: Yayasan Bina Pustaka Sarwono Prawirohardjo.

37. Yayasan Aspirasi Pemuda. 2001. Embriologi Kehamilan. http://www.yayasan-pemuda.com diakses tanggal 24 Maret 2009. 